\title{
$\mathrm{B} 16$ 멜라닌 세포에서 해양소재 추출물의 멜라닌 생성 저해 효과
}

\author{
이찬 ${ }^{1}$, 장정희 ${ }^{1}$, 안은미 ${ }^{2}$, 박찬익 $^{3 *}$
}

1 : 계명대학교 의과대학 약리학교실, 2 : 대구한의대학교 한방식품약리학과, 3 : 대구한의대학교 화장품약리학과

\section{Inhibitory Effects of Marine Natural Products on Melanogenesis in B16 Melanoma Cells}

\author{
Chan Lee ${ }^{1}$, Jung-Hee Jang', Eun-Mi Ahn², Chan-Ik Park ${ }^{3^{*}}$ \\ 1 : Department of Pharmacology, School of Medicine, Keimyung University \\ 2 : Daegu 704-701, Department of Herbal Food Pharmacology, Daegu Haany University \\ 3 : Department of Cosmeceutical Science, Daegu Haany University3, Gyeongsangbuk-do 712-220, Korea
}

\begin{abstract}
Objectives : Under normal condition melanin protects the skin from extracellular stimuli including ultraviolet (UV)-induced oxidative skin damages, but excess production and accumulation of melanin can induce hyperpigmentation causing esthetic problems. Therefore, in this study we tried to search for natural skin whitening materials from marine natural resources.

Methods : Water and ethanol extracts of marine natural resources were prepared from Porphyra thalli (PT), Laminariae thallus (LT), Ostreae concha (OC), Sargassum thallus (ST), Undaria thallus (UT), Codium thalli (CT), Enteromorpha thalli (ET), Syngnathoides biaculeatus (SB), and Hippocampus coronatus (Hc). Their effects against UVB and $\alpha$-melanocyte stimulating hormone ( $\alpha-\mathrm{MSH})$-induced melanogenesis were investigated based on melanin formation in B16 mouse melanoma cells. The mRNA and protein expression of enzymes involved in the melanogenic process were further examined by reverse transcriptase-polymerase chain reaction (RT-PCR) and Western blot analysis, respectively.

Results : Water extract of Ostreae concha (OCW/E) effectively inhibited UVB and $\alpha-\mathrm{MSH}$-induced melanin production in B16 melanocytes, which seemed to be mediated by inhibition of mRNA expression of tyrosinase and tyrosinase-related protein 1 (TRP-1). In another experiment, ethanol extracts from Porphyra thalli (PTE/E), Laminariae thallus (LTE/E), Sargassum thallus (STE/E), Undaria thallus (UTE/E), Codium thalli (CTE/E), Syngnathoides biaculeatus (SBE/E), and Hippocampus coronatus (HcE/E) significantly suppressed UVB and $\alpha$-MSH-induced melanin formation. Furthermore, ethylacetate fraction isolated form LTE/E (LTE/EEt) decreased UVB and $\alpha$-MSH-elevated extracellular melanin levels via inhibition of tyrosinase protein expression. Conclutions : These results suggest that marine natural resources such as Porphyra thalli, Laminariae thallus, Ostreae concha, Sargassum thallus, Undaria thallus, Codium thalli, Syngnathoides biaculeatus and Hippocampus coronatus have anti-melanogenic effects, thereby exhibiting high potentials to be utilized as one of the ingredients for the development of new whitening functional cosmetics.
\end{abstract}

Key words : B16 melanocytes, marine natural resources, melanogenesis, ultraviolet B

\section{서 론}

피부는 신체의 최외각 층을 형성하며 외부 유해물질로 부 터 내부기관을 보호하고 수분과 전해질의 손실을 막는 장벽기
능을 하는 대표적인 기관으로, 자외선(ultraviolet radiation, $\mathrm{UV})$, 중금속, 각종 산화 물질들과 같은 환경적 인자에 항상 노출되어 있어 손상을 받기 쉽다 ${ }^{1)}$. 특히 자외선 B (UVB)는 진피의 상부까지 도달하여 화상이나 홍반과 같은 염증을 일으

\footnotetext{
*교신저자 : 박찬익, 경북 경산시 상대로 115 길 3 대구한의대학교 오성캠퍼스 화장품약리학과

· Tel : 053-819-1491 · Fax : 053-819-1491·E-mail : cipark@dhu.ac.kr

- 접수 : 2012년 5월 13일 - 수정 : 2012년 6월 23일 - 채택 : 2012년 6월 28일
} 
키며 더 나아가 멜라닌(melanin) 생성을 촉진시켜 색소침착 을 유발한다 ${ }^{2)}$. 과량의 자외선 $\mathrm{B}$ 는 활성산소종을 다량으로 생 성하여 진피 결합조직의 손상과 함께 피부장벽을 붕괴시켜 노 화를 일으키며, 장기간 노출 시 심각한 피부 병변으로 이어져 피부세포 사멸 및 종양의 발생으로까지 이어진다).

멜라닌은 피부의 멜라닌소체(melanosome)에서 생성되며, 자외선이 유발하는 피부 손상으로부터 피부를 보호하는데 있 어 중요한 역할을 하는 것으로 알려져 있다. 하지만 장시간 자외선에 노출 되거나. 환경오염을 포함한 외부 자극요인과 호르몬, 염증유발인자 등의 내부 자극요인이 동시에 작용하는 경우, 멜라닌은 과잉으로 생성 및 축적되어 기미, 주근깨, 검 버섯, 과다색소침착증후군과 같은 피부장애를 일으키며, 피부 노화를 촉진하고 피부암을 유발하게 된다 ${ }^{4-5)}$.

자외선으로 인한 피부의 색소침착은 즉시 색소침착 (immediate pigment darkening, IPD)과 지연형 색소침착 (delayed tanning, DT)의 2가지 형태로 구분 할 수 있다 ${ }^{6-7)}$. 자외선 $\mathrm{B}$ 는 주로 지연형 색소침착을 유발하며, 노출 후 3-4일 내에 나타나 10일에서 3-4주에 최고에 달한다. 즉시 색소침착과 달리 염증과 화상을 동반하며, 멜라닌을 합성하는 효소인 tyrosinase의 활성과 멜라닌소체의 합성을 통해 새로 운 멜라닌의 생성을 증가 시킨다 ${ }^{8)}$. 따라서, 기존의 미백제는 멜라닌 합성의 중요한 효소인 tyrosinase의 저해 활성에 관 심이 집중되어 개발되어 왔다.

지금까지 tyrosinase의 활성을 억제하는 대표적인 미백제 로 히드로퀴논(hydroquinone), 알부틴(arbutin)과 코직산 (kojic acid) 등이 사용되어 왔으나, 히드로퀴논과 코직산의 경우 피부자극, 약한 미백효과, 세포독성 또는 돌연변이 등의 부작용을 유발하는 것으로 알려져 있다 ${ }^{9-11)}$. 그러므로, 더 안 전성이 높고 피부 친화력이 높아 효과를 극대화 할 수 있는 새로운 미백제를 찾고자 다양한 연구들이 진행되고 있으며, 그 중에서도 새로운 미백 천연소재에 대한 관심이 점차적으로 높아지고 있다. 현재 tyrosinase의 활성을 억제하는 것으로 보고된 천연소재로는 감초, 상백피, 녹차 등이 있으며, 이외 에도 다양한 천연소재를 이용한 미백 활성 및 기전 연구가 보 고 되고 있다 ${ }^{12-14)}$.

육상 식물에 비해 해양 식물이 수적으로 우세하며 다양성 을 가지고 있고, 상이한 생합성 경로를 가져 신규 활성물질을 다량 함유할 가능성에도 불구하고, 비용 및 노력 등의 측면으 로 상대적으로 많은 연구가 이루어 지지 않은 실정이다 ${ }^{15)}$. 해 양소재를 이용한 tyrosinase 활성 저해 효능을 가진 미백 천 연소재로는 모자반, 파래, 미역쇠, 감태 추출물, 감태로부터 분리한 활성물질 phlorotannins, 갈조류의 활성 성분중 하나 인 fucoidan 등이 제시된 바가 있다 ${ }^{15-21)}$.

본 연구에서는 마우스 흑색종 세포주(B16F10 mouse melanoma cells)을 사용하여 자외선 B (UVB) 조사와 멜라 닌 세포 자극 호르몬 $(\alpha$-melanocyte stimulating hormone, $\alpha-\mathrm{MSH})$ 처리로 유발된 세포독성과 멜라닌 생성 에 대한 다양한 해양소재 열수 및 에탄올 추출물들의 미백효 과를 검토하고자 하였다.

\section{1. 재료 및 시약}

세포배양을 위한 Dulbecco's modified Eagel's medium (DMEM) 배지, fetal bovine serum (FBS) 및 항생제 (penicillin/streptomycin)는 Gibco (Grand Island, NY, USA)사 제품을 구입하여 사용하였다. MTT [3-(4,5-dimethylthiazol-2-yl)-2,5-diphenyltetrazolium bromide], 멜라닌 세포 자극 호르몬 $(\alpha$-melanocyte stimulating hormone, $\alpha-\mathrm{MSH})$ 및 그 밖에 실험에 사용된 특급시약은 Sigma-Aldrich (St. Louis, MO, USA)사의 제 품을 사용하였다.

\section{2. 해양소재 추출물의 제조}

김(Porphyra thalli, PT), 다시마(Laminariae, LT), 모려 (Ostreae concha, OC), 모자반(Sargassum thallus, ST), 미역(Undaria thallus, UT), 청각(Codium thalli, CT), 파 래(Enteromorpha thalli, ET), 해룡(Syngnathoides biaculeatus, SB), 해마(Huppocampus coronatus, Hc)의 해양 소재는 2009년 9월에서 12월 사이 포항 죽도시장으로 부터 구입하여 대구한의대학교 $\mathrm{xx}$ 과에서 동정하여 실험에 사 용하였다. 해양소재로부터 염분을 수세하여 제거하고 7일간 건조시킨 뒤, 물을 가하여 3 시간 전탕 또는 $100 \%$ 에탄올을 가하여 상온에서 72 시간 동안 추출한 다음 No. 2 filter paper (Nalgene, New York, NY, USA)로 여과하였다. 여 액을 진공회전농축기(EYELA, Tokyo, Japan)와 동결건조기 (EYELA, Tokyo, Japan)를 사용하여 농축 및 동결 건조하였 으며, 실험에 사용 전 $-20^{\circ} \mathrm{C}$ 에서 보관하였다. 해양소재 열수 (water extract, W/E) 및 에탄올 추출물(ethanol extract, $\mathrm{E} / \mathrm{E})$ 의 최종 수율은 각각 김 $(\mathrm{PTW} / \mathrm{E}, \mathrm{PTE} / \mathrm{E}) 45.38 \%$, $0.58 \%$, 다시마(LTW/E, LTE/E) $2.74 \%, 1.19 \%$, 모려 $(\mathrm{OCW} / \mathrm{E}, \mathrm{OCE} / \mathrm{E}) 0.27 \%, 0.28 \%$, 모자반(STW/E, STE/E) $6.63 \%, 0.29 \%$, 미역(UTW/E, UTE/E) $3.32 \%, 0.32 \%$, 청 각 $(\mathrm{CTW} / \mathrm{E}, \mathrm{CTE} / \mathrm{E}) 5.8 \%, 0.73 \%$, 파래 $(\mathrm{ETW} / \mathrm{E}, \mathrm{ETE} / \mathrm{E})$ $13.15 \%, 1.45 \%$, 해룡(SBW/E, SBE/E) $15.82 \%, 1.47 \%$, 해 마 $(\mathrm{HcW} / \mathrm{E}, \mathrm{HcE} / \mathrm{E}) 14.23 \%, 3.78 \%$ 였다.

\section{3. 해양소재 에탄올 추출물 분획의 제조}

상기와 같이 건조된 다시마(Laminariae thallus; LT)를 미세하게 분쇄한 후 $70 \%$ 에탄올 수용액 $(0.5 \mathrm{~L} \times 3)$ 을 이용 하여 실온에서 24 시간 추출한 뒤 여과지로 여과하였다. 얻어 진 여액은 감압 농축하여 $70 \%$ 에탄올 추출물을 얻었다. 에탄 올 추출물의 일부를 용매 계통 분획하기 위하여 물 $(300 \mathrm{~mL})$ 과 ethyl acetate $(\mathrm{EtOAc}, 300 \mathrm{~mL} \times 3)$ 로 분배 추출하였 으며, 물층은 다시 $\mathrm{n}$-butanol $(\mathrm{n}-\mathrm{BuOH}, 300 \mathrm{~mL} \times 3)$ 로 분배 추출하였다. 각 층은 감압 농축하여 물 분획 $(\mathrm{LTE} / \mathrm{EW})$, $\mathrm{EtOAc}$ 분획(LTE/EEt) 및 $n-\mathrm{BuOH}$ 분획(LTE/EB)을 얻어 실험에 사용하였다.

\section{4. 세포배양}

B16 마우스 흑색종 세포(B16 mouse melanoma cells)는 
10\% FBS, penicillin $(10,000 \mathrm{IU} / \mathrm{ml})$ 및 streptomycin $(10,000 \mathrm{~g} / \mathrm{ml})$ 이 포함되어있는 DMEM 배지를 사용하여 3 $7{ }^{\circ} \mathrm{C}, 5 \% \mathrm{CO}_{2}$ 조건하에서 배양하였다. 배지는 2 일마다 새로 운 배지로 갈아주었으며, 실험을 위하여 $4 \times 10^{4}$ cells/well 또는 $1 \times 10^{5}$ cells/well 밀도로 세포를 각각 48-well 및 6-well culture plate에 분주하였다. 24시간 뒤 세포가 안정 적으로 부착되면 실험에 사용하였다.

\section{5. 세포생존율 측정(MTT dye reduction assay)}

B16 흑색종 세포를 48-well culture plate에 $4 \times$ $10^{4} \mathrm{cells} / w e l l$ 의 밀도로 접종 한 후 24 시간 뒤 세포가 안정적 으로 부착되면 해양소재 열수 및 에탄올 추출물, 분획물을 48-72시간 처리 하였으며, MTT를 최종 농도 $0.25 \mathrm{mg} / \mathrm{ml}$ 로 첨가하여 2 시간 동안 추가 배양하였다. 배지를 제거 한 다 음 dimethylsulfoxide (DMSO)를 $200 \mu$ l씩 가하여 formazan을 용해한 뒤 microplate reader (Emax, Molecular device, Sunnyvale, CA, USA)를 이용하여 540 $\mathrm{nm}$ 에서 흡광도를 측정하였다. 대조군의 세포생존율을 $100 \%$ 로 환산하여 상대적 생존율을 \%로 계산하였다.

\section{6. 멜라닌 생성 측정}

$\alpha-\mathrm{MSH}$ 처리 및 자외선 $\mathrm{B}$ 조사로 인한 멜라닌 생성에 대한 해양소재 추출물들의 효과를 검토하기 위하여, $\alpha-\mathrm{MSH}$ 를 $50 \mathrm{nM}$ 의 농도로 해양소재 열수 및 에탄올 추출물, 분획 물과 함께 24 시간 처리한 뒤, 배지를 걷어내고 인산완충용액 으로 1 회 세척한 다음 자외선 $\mathrm{B}$ 를 $30 \mathrm{~mJ} / \mathrm{cm}^{2}$ 의 강도로 조 사하였다. 자외선 B 조사 18-20시간 뒤, 배양액으로 유리된 멜라닌량을 $405 \mathrm{~nm}$ 에서 흡광도로 측정하였다(Emax, Molecular device).

\section{RNA 추출 및 $\mathrm{RT}-\mathrm{PCR}$}

\section{(reverse transcriptase-polymerase chain reaction)}

해양소재 추출물들이 멜라닌 생성에 관련된 효소들의 $\mathrm{mRNA}$ 발현에 미치는 영향을 비교 검토하기 위하여 $\mathrm{RT}-\mathrm{PCR}$ 을 실시하였다. 시약처리가 끝난 B16 흑색종 세포에 서 Invitrogen사의 TRIzol Reagent (Carlsbad, CA, USA) 를 사용하여 Total RNA를 추출하였다. M-MLV reverse transcriptase (Promega, WI, USA)를 사용하여 cDNA를 합성한 다음, 멜라닌 생성 관련 효소들의 유전자 발현을 비교 측정하기 위하여 $\mathrm{PCR}$ 을 수행하였다. $\mathrm{PCR}$ 은 $95^{\circ} \mathrm{C}$ 에서 5 분간 반응을 시킨 뒤, $95^{\circ} \mathrm{C} 30$ 초, $53-61^{\circ} \mathrm{C} 1$ 분, $72{ }^{\circ} \mathrm{C} 1$ 분을 33 cycle 수행 다음, $72^{\circ} \mathrm{C} 10$ 분간 더 반응시켰다. $\mathrm{PCR}$ 산물은 ethidium bromide $(\mathrm{EtBr})$ 를 포함하고 있는 1.0\% agarose gel에서 $50 \mathrm{~V}$ 로 전기영동 한 후, $\mathrm{BIO}-\mathrm{RAD}$ 사의 이미지 분 석 장비(Gel Doc XR System, CA, USA)를 이용하여 측정 하였다. $\mathrm{PCR}$ 에 사용된 멜라닌 생성 관련 효소의 프라이머 서 열은 다음과 같다.

\begin{tabular}{ccc}
\hline Gene & Forward & Reverse \\
\hline Tyrosinase & GGC CAG CTT TCA GGC AGA GGT & TGG TGC TTC ATG GGC AATC \\
\hline TRPI & GCT GCA GGA GCC TTC TTT CTC & AAG ACG CTG CAC TGC TGG TCT \\
\hline GAPDH & CAG CTG CAT GGC CAC ATC GG & AGT GTA GCC CAG GAT GCC CTT \\
\hline
\end{tabular}

\section{8. 단백질 분리 및 Western blot analysis}

멜라닌 생성 과정에서 속도결정단계에 작용하는 효소인 tyrosinase의 단백질 발현 변화를 검토하고자 Western blotting을 실시하였다. 시약처리가 끝난 B16 흑색종 세포를 phosphate buffered saline (PBS)로 1회 세척하고 ice cold RIPA buffer (Thermo Scientific, IL, USA)를 이용하여 얼 음위에서 30 분간 lysis시킨 다음 $15,000 \mathrm{rpm}$ 에서 15 분간 원 심분리하여 단백질을 분리하였다. $\mathrm{BCA}$ reagent로 단백질을 정량을 한 뒤, 단백질을 $10 \% \mathrm{SDS}-\mathrm{PAGE}$ 에서 전기영동 후 PVDF membrane (Pall Corporation, MI, USA)으로 transfer 하였다. 이후 membrane을 5\% non-fat dried milk로 blocking 시켰으며, anti-tyrosinase 및 anti-actin primary antibody를 이용하여 $4{ }^{\circ} \mathrm{C}$ 에서 overnight으로 반응 시켰다. PBST용액(0.01\% Tween-20을 포함하는 PBS)으로 10 분간 3 회 추가 세척한 뒤, horseradish peroxidase (HRP)-conjugated secondary antibody를 1시간 동안 실온 에서 붙였다. 다시 $\mathrm{PBST}$ 용액으로 10 분간 3 회 세척한 다음 membrane을 enhanced chemoluminescence (ECL) reagent (Amersham Pharmacia Biotech., IL, USA)를 사 용하여 1 분간 반응시킨 뒤 이미지 분석 장비(LAS4000 Imaging, Fujifilm, Tokyo, Japan)를 이용하여 촬영 분석하 였다.

\section{결과 및 고찰}

\section{1. 해양소재 열수 추출물이 멜라닌세포 생존율 에 미치는 효과}

다양한 농도 $(0.1,0.3,1 \mathrm{mg} / \mathrm{ml})$ 의 해양소재 열수 추출물 을 $\mathrm{B} 16$ 흑색종 세포에 72 시간 동안 처리하고 $\mathrm{MTT}$ reduction assay로 세포생존율을 비교 측정하였다. 결과, 대 부분의 해양소재 $0.3 \mathrm{mg} / \mathrm{ml}$ 이하의 농도에서는 세포 생존율 에 큰 영향을 주지 않았으며, $1 \mathrm{mg} / \mathrm{ml}$ 농도로 처리시 청각 $(\mathrm{CTW} / \mathrm{E})$ 과 파래 $(\mathrm{ETW} / \mathrm{E})$ 열수 추출물을 제외하고 세포 증식 을 억제하였으며, 독성을 나타내었다(Figure 1). 한편, 김 (PTW/E)과 파래 $(\mathrm{ETW} / \mathrm{E})$ 열수 추출물은 저농도 $(0.1 \mathrm{mg} / \mathrm{ml})$ 에서 $\mathrm{B} 16$ 흑색종 세포의 증식을 촉진시키는 것으로 나타났 다. 멜라닌세포의 증식을 촉진하거나 억제하는 물질 보다 대 체로 세포독성을 나타내지 않으면서 멜라닌의 생성을 억제하 는 물질이 좋은 미백 기능성 물질이라 할 수 있으므로, 이를 바탕으로 해양소재 열수 추출물들이 자체 독성을 나타내지 않 는 두 개의 농도를 설정하여 이후 멜라닌 생성에 미치는 효능 검증 실험을 수행하였다. 


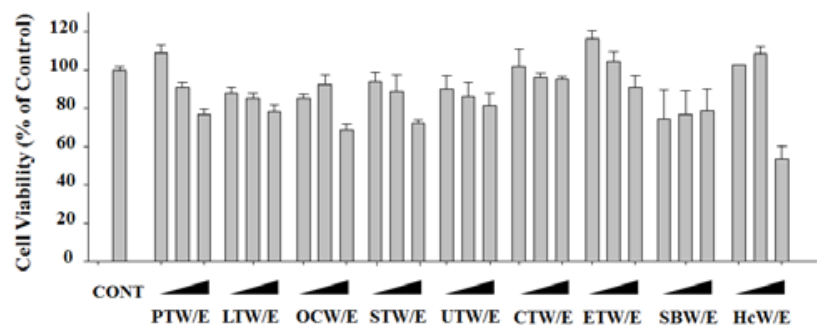

Fig. 1 Effects of water extracts from marine natural resources on the cell viability in B16 melanocytes B16 melanoma cells were treated with various concentrations $(0.1,0.3,1 \mathrm{mg} / \mathrm{ml})$ of water extracts of Porphyra thalli (PTW/E), Laminariae thallus (LTW/E), Ostreae concha (OCW/E), Sargassum thallus (STW/E), Undaria thallus (UTW/E), Codium thalli (CTW/E), Enteromorpha thalli (ETW/E), Syngnathoides biaculeatus (SBW/E), and Hippocampus coronatus (HcW/E) for $72 \mathrm{~h}$. Cell viability was determined by MTT dye reduction assay. Data are represented as mean \pm S.D. $(n=3)$ regarding control group as $100 \%$.

\section{2. 멜라닌 생성에 대한 해양소재 열수 추출물의}

\section{억제 효과}

이후 실험에서는 다양한 해양소재 열수 추출물이 멜라닌 합성에 미치는 영향을 확인하기 위하여 B16 흑색종 세포를 이용하여 $\alpha-\mathrm{MSH}$ 와 자외선 $\mathrm{B}$ 로 인해 세포배양 배지로 유리 된 멜라닌 양을 측정하였다. 멜라닌세포 자극 호르몬인 $\alpha$ $-\mathrm{MSH}$ 는 뇌하수체 중엽에서 갑상선 자극호르몬(thyroid stimulating hormone, TSH)과 부신피질 자극호르몬 (adrenocorticotropic hormone, ACTH)에 의해 분비가 촉진 되며 멜라닌세포를 활성화 시키는 역할을 한다 ${ }^{22)}$. 세포내 분 자생물학적 기전으로 $\alpha-\mathrm{MSH}$ 는 melanocortin receptor 1 $(\mathrm{MC1R})$ 과 결합하여, GTP-binding protein인 Gs 단백질을 활성화 시키며, 이후 adenylate cyclase를 통해 cAMP 증가 를 유발한다 ${ }^{23)}$. 증가된 $\mathrm{cAMP}$ 는 protein kinase $\mathrm{A}(\mathrm{PKA})$ 와 c-AMP response element-binding oriten (CREB)를 활성 화 시키며, 전사인자 $\mathrm{CREB}$ 는 microphthalmia-associated transcription factor (MITF) 단백질 발현을 촉진시켜 tyrosinase, TRP-1, TRP-2의 합성을 통해 멜라닌 특히 eumelanin의 생성을 증가시키는 것으로 알려져 있다 ${ }^{23)}$.

$\mathrm{B} 16$ 흑색종 세포에 $\alpha-\mathrm{MSH}(50 \mathrm{nM})$ 를 24 시간 처리한 다음 자외선 $\mathrm{B}$ 를 $30 \mathrm{~mJ} / \mathrm{cm}^{2}$ 로 조사한 경우 18 시간 뒤 배지 내 멜라닌 함량이 $288.2 \%$ 정도로 증가되었으며, 이는 모려 $(\mathrm{OCW} / \mathrm{E}, 0.3 \mathrm{mg} / \mathrm{ml})$ 열수 추출물을 함께 처리한 그룹에서 $166.7 \%$ 로 유의적으로 감소됨을 확인 할 수 있었다(Figure 2). 하지만, 열수 추출물들은 대체적으로 멜라닌 생성 억제에 있어 낮은 활성을 나타내었다. 일반적으로 피부는 자외선에 급성으로 노출된 경우 홍반, 발진, 부종, 통증, 소양증이 일 차적으로 유발되며, 이후 피부 색소침착, 표피 비후 더 나아 가 만성적 노출로 인해 노화와 육종형성 일어난다. ${ }^{24)}$ 이러한 자외선으로 인한 손상에 대해 멜라닌 세포는 멜라닌 합성을 증가시켜 각질형성세포로 이동시킴으로써 일광에 의한 피부 손상을 방지하고자 한다. 하지만, 과도한 자외선 노출은 색소 침착을 촉진하며, 동일양의 자외선 $\mathrm{B}$ 를 반복 분할 조사한 경 우에 비해 일회 조사한 경우 멜라닌세포의 성장이 더욱 억제 되며 멜라닌화가 촉진되는 것으로 보고되었다 ${ }^{24)}$. 특히, $\alpha$
$-\mathrm{MSH}$ 와 자외선을 병합 처치시 피부색소 증가에 상승적으로 작용하며, 이는 자외선 조사가 강력한 cAMP activator로 작 용하여 멜라닌세포의 $\alpha-\mathrm{MSH}$ 수용체 활성을 증진시키기 때 문으로 제시되었다 ${ }^{25)}$. 따라서, 본 연구에서는 화학적 $(\alpha$ $-\mathrm{MSH}$ ) 및 물리적(자외선 B) 인자를 동시에 이용하여, 단기 간에 강력한 멜라닌 생성 시스템을 도입함으로써 다양한 해양 소재 열수 및 에탄올 추출물, 분획물들의 활성을 검토하고자 하였다.

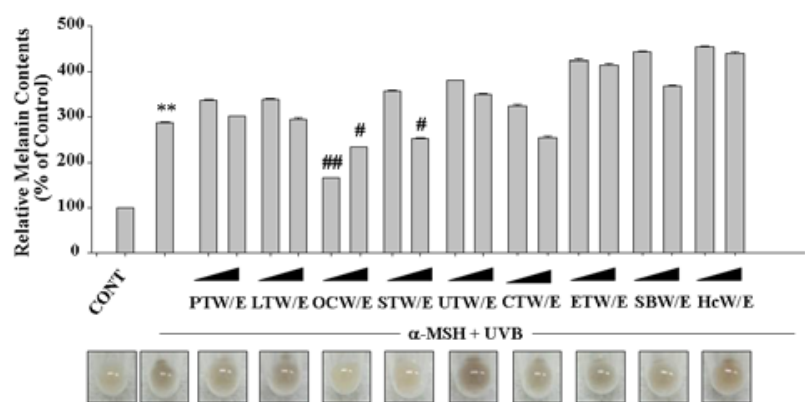

Fig. 2 Inhibitory effects of water extracts from marine natural resources on $\alpha-\mathrm{MSH}$ and UVB-induced melanin formation in B16 melanocytes B16 melanoma cells were treated with $0.3 \mathrm{mg} / \mathrm{ml}$ or $1 \mathrm{mg} / \mathrm{ml}$ water extracts of Porphyra thalli (PTW/E), Laminariae thallus (LTW/E), Ostreae concha (OCW/E), Sargassum thallus (STW/E), Undaria thallus (UTW/E), Codium thalli (CTW/E), Enteromorpha thalli (ETW/E), Syngnathoides biaculeatus (SBW/E), and Hippocampus coronatus (HcW/E) for $24 \mathrm{~h}$ in combination with $50 \mathrm{nM} \alpha-\mathrm{MSH}$ and then exposed to $30 \mathrm{~mJ} / \mathrm{cm}^{2}$ UVB. After additional incubation for $18 \mathrm{~h}$, the extracellular contents of melanin were measured by colorimetric analysis at $405 \mathrm{~nm}$ as described in Materials and Methods. Data are shown as mean \pm S.D. $(n=3)$.

\section{3. 멜라닌 생성에 대한 해양소재 열수 추출물의 억제 기전}

한편, 모려 열수 추출물 $(\mathrm{OCW} / \mathrm{E})$ 에 의해 멜라닌 생성이 억 제되는 기전을 규명하기 위하여 멜라닌 생성과 관련된 여러 단백질들의 $\mathrm{mRNA}$ 발현을 $\mathrm{RT}-\mathrm{PCR}$ 로 비교 측정하였다. 멜라 닌은 L-tyrosine으로부터 일련의 산화 중합반응을 통하여 형 성되며 이러한 과정에서 tyrosinase가 중요한 역할을 하게 된 다. 즉, L-tyrosine으로부터 3,4-dihydroxyphenylalanine (DOPA), dopaquinone, dopachrome, 5,6-dihydroxyindole (DHI), 5,6-dihydroxyindole-2-carboxylic acid (DHICA) 를 형성하고 중합반응을 거쳐 멜라닌이 형성되는데, 이 과정 에서 초기 속도결정단계에 tyrosinase가 tyrosine hydroxylase와 DOPA oxidase로 핵심적인 작용을 한다 22,26,27). 그 밖에 멜라닌 합성 관련 효소로 $\mathrm{DHICA}$ 를 indole-5,6-quinone-2-carboxylic acid로 산화하는 효소 인 tyrosinase-related protein 1 (TRP-1, DHICA oxidase)와 dopachrome을 DHICA로 이성화 하는 효소 tyrosinase-related protein 2 (TRP-2, DOPA chrome tautomerase : $\mathrm{DCT}$ ) 등이 있다 ${ }^{22,26,27)}, \alpha-\mathrm{MSH}$ 와 자외선 $\mathrm{B}$ 를 조사한 경우 $\mathrm{B} 16$ 흑색종 세포에서 tyrosinase와 $\mathrm{TRP}-1$ 의 mRNA 발현이 현저히 증가되었으며, 이는 모려 열 수 추출물 $(\mathrm{OCW} / \mathrm{E}, 0.1,0.3 \mathrm{mg} / \mathrm{ml})$ 을 처리한 경우 농도 의존적으로 현저히 감소되었다(Figure 3 ). 
A

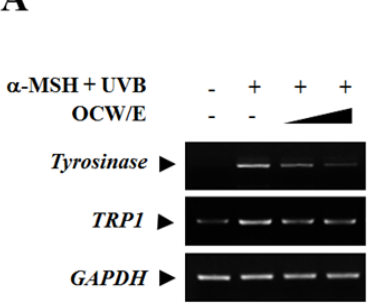

B

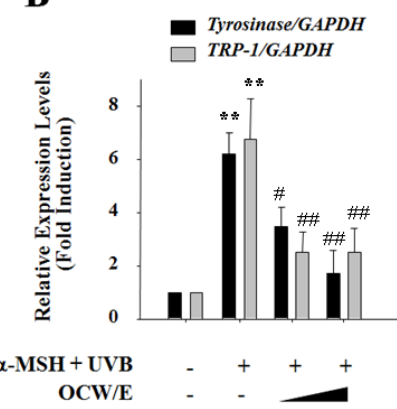

Fig. 3 Effect of Ostreae concha water extract (OCW/E) on the mRNA expression of enzymes involved in the melanin formation B16 melanoma cells were treated with OCW/E $(0.1 \mathrm{mg} / \mathrm{ml}$ and $0.3 \mathrm{mg} / \mathrm{ml}$ ) for $24 \mathrm{~h}$ in combination with $\alpha-\mathrm{MSH}(50 \mathrm{nM})$ and then exposed to UVB $\left(30 \mathrm{~mJ} / \mathrm{cm}^{2}\right)$. The mRNA expression of tyrosinase and TRP-1 was determined by RT-PCR. The representative image of DNA gel electrophoresis and quantification data of relative band intensity were shown in $A$ and $B$, respectively. GAPDH levels were measured for the confirmation of equal loading of mRNA.

\section{4. 멜라닌 생성에 대한 해양소재 에탄올 추출물 의 억제 효과}

다음으로, 해양소재 에탄올 추출물을 다양한 농도 $(10,30$, $100 \mu \mathrm{g} / \mathrm{ml}$ 로 $\mathrm{B} 16$ 흑색종 세포에 48시간 동안 처리하고 열수 추출물과 동일한 방법으로 MTT dye reduction assay 를 통해 세포생존율에 미치는 영향을 검토하였다. 에탄올 추 출물의 경우 모자반(STE/E)을 제외하고 $30 \mu \mathrm{g} / \mathrm{ml}$ 이하의 농도에서는 세포 독성을 보이지 않았으며, 세포 증식에도 큰 영향을 미치지 않았다(Figure 4). 이상의 자체독성 결과를 바 탕으로 멜라닌 세포에 독성을 나타내지 않는 두 가지 농도를 설정하여, 이후 실험에서는 해양소재 에탄올 추출물이 멜라닌 합성에 미치는 영향을 확인하기 위하여 세포배양 배지로 유리 된 멜라닌 양을 측정하였다. 에탄올 추출물을 $50 \mathrm{nM} \alpha$ $-\mathrm{MSH}$ 와 함께 24 시간 전처리한 다음 자외선 $\mathrm{B}$ 를 30 $\mathrm{mJ} / \mathrm{cm}^{2}$ 로 조사한 경우, 20 시간 뒤 배지 내 멜라닌 함량이 $415.5 \%$ 정도로 증가되었으며, 이는 김(PTE $/ \mathrm{E}, 30 \mu \mathrm{g} / \mathrm{ml})$, 다시마(LTE $/ \mathrm{E}, 100 \mu \mathrm{g} / \mathrm{ml}$ ), 모자반(STE/E, $10 \mu \mathrm{g} / \mathrm{ml})$, 미역(UTE $/ \mathrm{E}, 3 \mu \mathrm{g} / \mathrm{ml})$, 청각 $(\mathrm{CTE} / \mathrm{E}, 30 \mu \mathrm{g} / \mathrm{ml})$, 해룡 $(\mathrm{SBE} / \mathrm{E}, 10 \mu \mathrm{g} / \mathrm{ml})$, 해마 $(\mathrm{HcE} / \mathrm{E}, 100 \mu \mathrm{g} / \mathrm{ml})$ 를 처리한 경우 멜라닌 생성이 각각 $131.8 \%, 180.7 \%, 162.8 \%$, $112.7 \%, 144.8 \%, 163.5 \%, 183.4 \%$ 로 유의적으로 감소되는 것을 확인 할 수 있었다(Figure 5).

김은 홍조류에 속하는 해조류로 풍부한 영양소를 가지고 있으며, 탄수화물로는 mannan과 xylan 등의 난용성 섬유와 prophyran 등의 수용성 다당류를 함유하며, 그 밖에 각종 비타민, 무기질, eicosapentaenoic acid (EPA)와 타우린 (taurine), 항산화 폴리페놀 등이 활성물질로 존재하여 다양 한 생리활성을 나타내는 것으로 알려져 있다 ${ }^{28)}$. 다시마는 갈 조류에 속하는 해조류로 곤포 또는 해태라 하며 탄수화물을 $49 \%$ 로 다량 가지고 있으며, 이 중 5-10\%를 섬유소로, 나머 지는 알긴산을 주체로 한 laminaran과 fucoidan 등의 당류
를 포함하고 있다 ${ }^{29)}$. 특히, 당대사 조절, 항균, 항바이러스, 정장, 중금속 배출, 항콜레스테롤, 항혈액응고, 항종양 작용이 있는 것으로 보고되었다. ${ }^{29)}$ 모자반은 갈조류에 속하는 해조류 로 식품 및 의약적 용도로 오래 동안 사용되어 왔으며, 특히 전통의학에서 습진, 옴, 건선 등의 피부질환, 신기능 손상, 심장질환, 폐질환, 위궤양, 담즙 분비의 목적으로 이용되었다 ${ }^{30)}$. 특히, 이전 연구에서 모자반 에탄올 추출물과 헥산 분획 물의 경우 $\mathrm{B} 16$ 흑색종 세포에서 $\alpha-\mathrm{MSH}$ 로 유도된 멜라닌 생성 및 tyrosinase 활성을 효과적으로 억제하는 것으로 보 고되었다 ${ }^{30)}$. 미역은 갈조류에 속하는 해조류로 단백질, 지질, 비타민 등 영양소를 고루 함유하고 있을 뿐 아니라 칼슘과 요 오드 등의 무기질을 풍부하게 가지고 있다. ${ }^{31)}$ 미역은 혈압강 화, 항당뇨, 혈중 콜레스테롤 개선, 신진대사 촉진, 변비 및 비만예방, 노화방지, 피부미용, 항산화 등 광범위한 생리활성 을 가지는 것으로 연구되어져 왔다 ${ }^{31}$. 청각은 녹조류에 속하 는 해조류로 식용소재로 사용되어 왔으며, 민간요법으로 구충 제, 비뇨기 질환 및 수종 치료에 이용되었다. ${ }^{32)}$ 청각에는 항 생작용을 갖는 acrylic acid 뿐 아니라 항 응고활성, 항암, 항돌연변, 면역활성을 갖는 물질이 함유되어 있는 것으로 알 려져 있다 ${ }^{32)}$.

한편, 모려는 열수 추출물 $(\mathrm{OCW} / \mathrm{E})$ 로 처리시 멜라닌 생성 감소 효과가 있었지만, 에탄올 추출물 $(\mathrm{OCE} / \mathrm{E})$ 의 경우 멜라닌 생성 억제 효능을 관찰 할 수 없었다. 이는 각기 다른 용매로 추출시 활성성분의 종류 및 량의 차이에 기인하는 것으로 사 료된다. 모려는 굴의 껍질로 제산, 지갈, 지한, 해열, 진통, 진정약으로 위산과다, 도한, 몽정, 정신불안증에 사용되어 왔 다 ${ }^{33)}$. 특히, 굴 껍질을 이루고 있는 탄산칼슘, 인산칼슘, 마 그네슘, 알루미늄, 규소, 산화철 등에 유착되어 있는 콘키올 린(conchiolin)이라는 연체동물 특유의 물질이 활성성분 중 하나로 제시되었으며, 이는 RAW 264.7 세포에서 lipopolysaccharide (LPS)로 유도된 다양한 염증반응 즉 염 증매개 효소[inducible nitric oxide (iNOS), cyclooxygenase-2 $(\mathrm{COX}-2)]$ 및 물질tumor necrosis factor- $\alpha \quad(\mathrm{TNF}-\alpha)$, interleukin-6 (IL-6)]의 발현 억제 를 통해 항염증 작용을 가지는 것으로 보고되었다 ${ }^{34)}$.

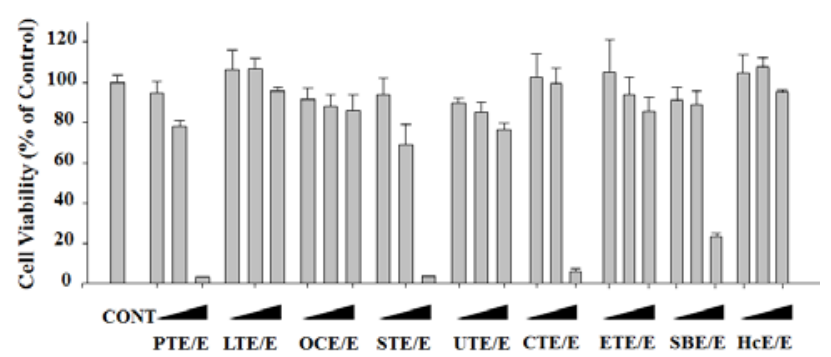

Fig. 4 Effects of ethanol extracts from marine natural resources on the cell viability in B16 melanoma cells B16 melanocytes were treated with diverse concentrations $(10,30,100 \mu \mathrm{g} / \mathrm{ml})$ of ethanol extracts of Porphyra thalli (PTE/E), Laminariae thallus (LTE/E), Ostreae concha (OCE/E), Sargassum thallus (STE/E), Undaria thallus (UTE/E), Codium thalli (CTE/E), Enteromorpha thalli (ETE/E), Syngnathoides biaculeatus (SBE/E), and Hippocampus coronatus (HcE/E) for $48 \mathrm{~h}$. The cell viability was assessed by MTT dye reduction assay. Data are described as mean \pm S.D. $(n=3)$ regarding control group as $100 \%$. 


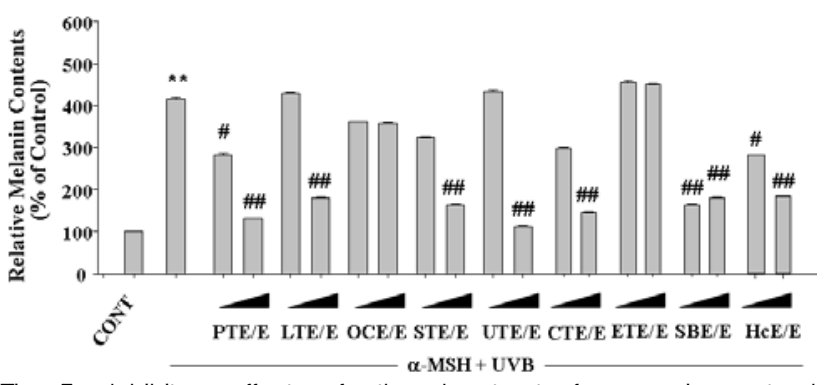

Fig. 5 Inhibitory effects of ethanol extracts from marine natural resources on $\alpha-\mathrm{MSH}$ and UVB-induced melanin formation in B16 melanomc cells B16 melanocytes were treated with PTE/E (10, $30 \mu \mathrm{g} / \mathrm{ml})$, LTE/E (30, $100 \mu \mathrm{g} / \mathrm{ml})$, OCE/E (30, $100 \mu \mathrm{g} / \mathrm{ml})$, STE/E (3, $10 \mu \mathrm{g} / \mathrm{ml})$, UTE/E (1, $3 \mu \mathrm{g} / \mathrm{ml})$, CTE/E $(10,30 \mu$ $\mathrm{g} / \mathrm{ml}), \mathrm{ETE} / \mathrm{E}(10,30 \mu \mathrm{g} / \mathrm{ml}), \mathrm{SBE} / \mathrm{E}(10,30 \mu \mathrm{g} / \mathrm{ml})$, and HCE/E (30, $100 \mu \mathrm{g} / \mathrm{ml})$ for $24 \mathrm{~h}$ in combination with $50 \mathrm{nM} \alpha-\mathrm{MSH}$ and then exposed to $30 \mathrm{~mJ} / \mathrm{cm}^{2}$ UVB. After additional incubation for $20 \mathrm{~h}$, the extracellular melanin levels were measured by absorbance at $405 \mathrm{~nm}$. Data are represented as mean \pm S.D. $(n=3)$.

\section{5. 멜라닌 생성에 대한 해양소재 분획물의 억제 효과 및 기전}

상기 실험 결과를 바탕으로 멜라닌 생성 억제 효능을 갖는 활성 분획물을 규명하기 위하여, 우선 다시마 에탄올 추출물 을 대상으로 일련의 실험을 수행하였다. 우선, 다시마 에탄올 추출물 $(\mathrm{LTE} / \mathrm{E})$ 의 에틸아세테에트 분획(LJE/EEt), 부탄올 분 획(LJE/EB), 물분획(LJE/EH)을 $10,30,100 \mu \mathrm{g} / \mathrm{ml}$ 의 농 도로 단독으로 48 시간 동안 처리하고 세포생존에 미치는 영 향을 MTT dye reduction assay로 살펴보았으며, 결과 대부 분의 경우 세포독성을 나타내지 않았으며(Figure 6A), 이후 실험에서는 세포독성을 나타나지 않은 두 개의 농도를 설정하 여 각각의 분획물들이 멜라닌 합성에 미치는 영향을 확인하기 위하여, 배지 내 유리된 멜라닌 생성량을 측정하였다. $\alpha$ $-\mathrm{MSH}(50 \mathrm{nM})$ 를 분획물들과 함께 24 시간 처리한 다음 자 외선 $\mathrm{B}$ 를 $30 \mathrm{~mJ} / \mathrm{cm}^{2}$ 로 조사한 경우 20 시간 뒤 멜라닌 함량 을 측정한 결과 $388.9 \%$ 정도로 증가되었으며, 이는 다시마 에탄올 추출물의 에틸아세테이트 분획물 $(\mathrm{LJE} / \mathrm{EEt})$ 을 함께 처 리한 그룹에서 $166.7 \%$ 로 가장 현저히 감소됨을 확인 할 수 있었다(Figure 6B). 한편, 다시마 에틸아세테이트 분획물 (LJE/EEt)에 의해 멜라닌 생성이 억제되는 기전을 규명하기 위하여 멜라닌 생성 속도결정 단계에 작용하는 효소 tyrosinase의 단백질 발현을 Western blot analysis로 측정 비교하였다. $\alpha-\mathrm{MSH}$ 와 자외선 $\mathrm{B}$ 를 조사한 경우 $\mathrm{B} 16$ 흑색 종 세포에서 tyrosinase의 단백질 발현이 현저히 증가되었으 며, 이는 다시마 에틸아세테이트 분획물(LJE/EEt, 30, 100 $\mu \mathrm{g} / \mathrm{ml})$ 을 처리한 경우 농도 의존적으로 현저히 감소되었으 며, 다시마 에탄올 추출물 보다 더 높은 활성을 나타내었다 (Figure 7). 이전의 연구에서 다시마 열수 추출물이 B16 흑 색종 세포에서 $\alpha-\mathrm{MSH}$ 에 의한 tyrosinase 활성과 멜라닌 생성을 억제하는 것으로 보고하였지만, 본 연구에서는 $\alpha$ $-\mathrm{MSH}$ 와 자외선 $\mathrm{B}$ 로 유도된 멜라닌 생성과 tyrosinase 발현 증가에 대해 다시마 에탄올 추출물과 에틸아 테이트 분획이 최적의 효과를 나타내었다. ${ }^{29)}$

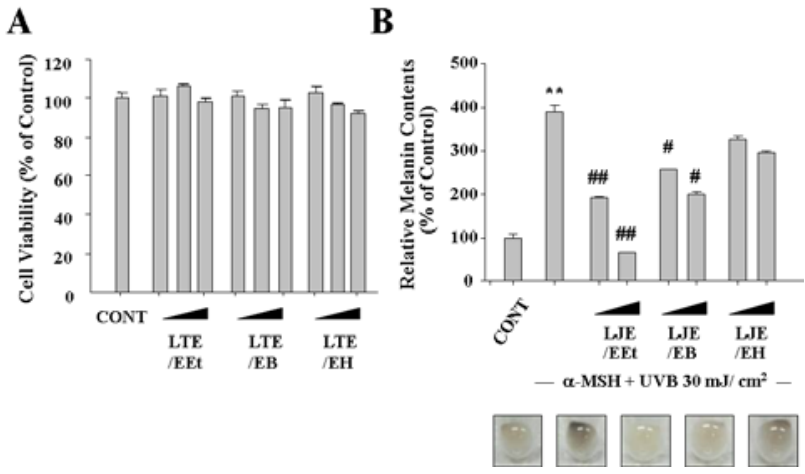

Fig. 6 Effects of diverse fractions derived from ethanol extract of Laminariae thallus (LTE/E) on the cell viability and $\alpha-\mathrm{MSH}$ and UVB-induced melanin formation in B16 melanoma cells A. Cells were treated with different concentrations $(10,30,100 \mu \mathrm{g} / \mathrm{ml})$ of ethylacetate (LTE/EEt), buthanol(LTE/EB), and water(LTE/EW) fractions of LTE/E for $48 \mathrm{~h}$. The cell viability was determined by MTT dye reduction assay. B. Cells were treated with LTE/EEt, LTE/EB, and LTE/EW $(30 \mu \mathrm{g} / \mathrm{ml}$ and $100 \mu \mathrm{g} / \mathrm{ml})$ for $24 \mathrm{~h}$ in the presence of $50 \mathrm{nM} \alpha-\mathrm{MSH}$ and then $30 \mathrm{~mJ} / \mathrm{cm}^{2}$ UVB was irradiated. The extracellular melanin contents were measured by colorimetric assay at $405 \mathrm{~nm}$. Data are described as mean \pm S.D. $(n=3)$.
$\mathbf{A}$

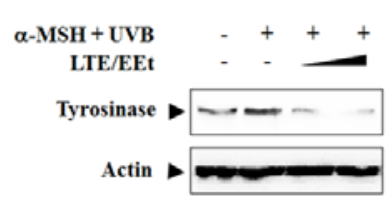

B

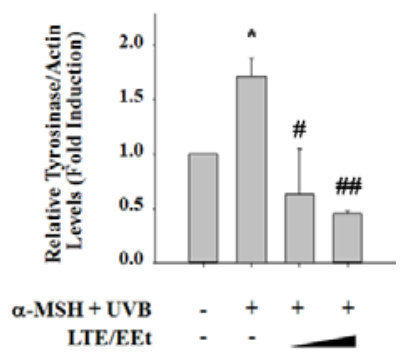

Fig. 7 Effect of ethylacetate fraction of Laminariae thallus ethanol extract (LTE/EEt) on the protein levles of tyrosinase in B16 melanoma cells B16 cells were treated with LTE/EEt $(30 \mu \mathrm{g} / \mathrm{ml}$ and $100 \mu \mathrm{g} / \mathrm{ml})$ for $24 \mathrm{~h}$ in the presence of $\alpha-\mathrm{MSH}(50 \mathrm{nM})$ and then UVB $\left(30 \mathrm{~mJ} / \mathrm{cm}^{2}\right)$ was irradiated. The protein expression of tyrosinase was analyzed by Immunoblotting using anti-tyrosinase antibody. The representative image (A) and quantification data of tyrosinase-specific bands (B) were represented. Actin levels were monitored for the confirmation of equal amount of protein loaded.

\section{결 론}

본 연구에서는 $\mathrm{B} 16$ 마우스 흑색종 세포에서 $\alpha-\mathrm{MSH}$ 와 자외선 $\mathrm{B}$ 로 유도된 멜라닌 생성에 대한 천연 해양소재의 열 수 및 에탄올 추출물과 그 분획물의 억제 활성을 검토하여 미 백제로서의 개발 가능성을 검토하고자 하였으며 다음과 같은 결론을 얻었다.

1. 모려 열수 추출물 $(\mathrm{OCW} / \mathrm{E})$, 김 $(\mathrm{PTE} / \mathrm{E})$, 다시마 $(\mathrm{LTE} / \mathrm{E})$, 모자반 $(\mathrm{STE} / \mathrm{E})$, 미역 $(\mathrm{UTE} / \mathrm{E})$, 청각 $(\mathrm{CTE} / \mathrm{E})$, 해룡 $(\mathrm{SBE} / \mathrm{E})$, 해마 $(\mathrm{HcE} / \mathrm{E})$ 에탄올 추출물, 다시마 에탄올 추출 물의 에틸아세테이트 분획(LJE/EEt)이 유의적으로 멜라닌 생 성을 감소시킴을 확인하였다. 
2. 특히, 모려 열수 추출물(OCW/E)과 다시마 에틸아세테 이트 분획(LJE/EEt)로 인한 멜라닌 생성 감소는 멜라닌 합성 에 관여하는 효소인 tyrosinase 및 TRP-1의 발현 억제에 의 한 것으로 사료된다.

이상의 결과는 해양소재 모려, 김, 다시마, 모자반, 미역, 청각, 해룡, 해마가 피부의 미백에 도움을 주는 기능성 화장 품의 천연 소재로서의 활용 가능성을 시사하는 것으로 사료되 며 해양 소재의 미백 효능 메커니즘을 심도있게 규명하기 위 해서는 지속적인 연구가 필요할 것으로 사료된다.

\section{감사의 글}

본 연구는 농림수산식품부 수산특정연구개발사업의 연구비 지원에 의해 수행되었으며 이에 감사드립니다.

\section{참고문헌}

1. Lee WJ. Structure and function. J Skin Barrier Research. 2006 ; 8 : 10-7.

2. Shimoda N, Mutou Y, Shimura N, Tsukimoto M, Awaya A, Kojima S. Effect of heterocyclic pyrimidine compounds on UVB-induced cell damage in human keratinocytes and on melanogenesis in mouse B16 cells. Biol Pharm Bull. 2010 ; 33 : 862-8.

3. Svobodova A, Walterova D, Vostalova J. Ultraviolet light induced alteration to the skin. Biomed Pap Med Fac Univ Palacky Olomouc Czech Repub. 2006 ; 150 : 25-38.

4. Costin GE, Hearing VJ. Human skin pigmentation: melanocytes modulate skin color in response to stress. FASEB J. 2007 ; 21 : 976-94.

5. James JN, Raymond EB, Vincent JH, Richard AK, William SO, Jean-Paul O. The Pigmentary System: Physiology and Pathophysiology. 2nd Edition. Wiley-Blackwell. 2006.

6. Irwin C, Barnes A, Veres D, Kaidbey K. An ultraviolet radiation action spectrum for immediate pigment darkening. Photochem Photobiol. 1993 ; 57 : 504-7.

7. Kawada A. UVB-induced erythema, delayed tanning, and UVA-induced immediate tanning in Japanese skin. Photodermatol. 1986 ; 3 : 327-33.

8. Ortonne JP. The effects of ultraviolet exposure on skin melanin pigmentation. J Int Med Res. 1990 ; 18 : 8C-17C.

9. Chakraborty AK, Funasaka Y, Komoto M, Ichihashi M. Effect of arbutin on melanogenic proteins in human melanocytes. Pigment Cell Res. 1998 ; 11 : 206-12.
10. Halder RM, Richards GM. Topical agents used in the management of hyperpigmentation. Skin Therapy Lett. $2004 ; 9: 1-3$.

11. Maeda K, Fukada M. In vivo effectiveness of several whitening cosmetic components in human melanocytes. J Soc Cosmet Chem. 1991 ; 42 : 361-8.

12. Lee JS, Kim JA, Cho SH, Son AR, Jang TS, So MS, Chung SR, Lee SH. Tyrosinase inhibitors isolated from the roots of glycyrrhiza glabra $\mathrm{L}$. Kor J Pharmacogn. 2003 ; 34 : 33-9.

13. You MJ. Inhibitory Effect of Morus alba Extracts on Tyrosinase Activity and Melanogenesis in SK-MEL-2 cells. Kor J Aesthet Cosmetol. 2011 ; 9 : 19-30.

14. No JK, Soung DY, Kim YJ, Shim KH, Jun YS, Rhee SH, Yokozawa T, Chung HY. Inhibition of tyrosinase by green tea components. J Life Sci. 1999 ; 65 : PL241-6.

15. Lee HJ, Kim JH, Lee CH, Kim JS, Kwak ST, IEE $\mathrm{KB}$, Song KS, Choi BW, Lee BH. Inhibitory activities of sea weeds on prolyl endopeptidase, tyrosinase and coagulation. Kor J Pharmacogn. $1999 ; 118: 231-7$

16. Kang KJ, Choi BW, Lee BH, Lee ES, Lee NH. Screening of the Tyrosinase Inhibitors from Marine Algae and Medicinal Plants. Kor J Pharmacogn. $1998 ; 114: 237-42$.

17. Chan YY, Kim KH, Cheah SH. Inhibitory effects of Sargassum polycystum on tyrosinase activity and melanin formation in B16F10 murine melanoma cells. J Ethnopharmacol. 2011 ; 137 : 1183-8.

18. Cho YH. Inhibitory effect of Enteromorpha linza on the melanogenesis in B16 melanoma cells. Kor J Pharmacogn. 2008 ; 39 : 174-8.

19. Yoon HS, Ko WB, Jung JH, Kim IJ. The anti-melanogenic effects of petalonia binghamiae extracts in uurine B16/F1 melanoma cells. J subtropical agriculture and biotechnology. 2009 ; $25: 25-31$.

20. Yoon NY, Eom TK, Kim MM, Kim SK. Inhibitory effect of phlorotannins isolated from Ecklonia cava on mushroom tyrosinase activity and melanin formation in mouse B16F10 melanoma cells. J Agric Food Chem. 2009 ; 57 : 4124-9.

21. Jung $\mathrm{SH}, \mathrm{Ku} \mathrm{MJ}$, Moon HJ, You BC, Jun MJ, Lee YH. Inhibitory Effects of Fucoidan on Melanin Synthesis and Tyrosinase Activity. J Life Sci. 2009 ; 19 : 75-80.

22. Li SH, Ryu JY, Zhang R, Yoo HS, Kim JH, Kwon TJ, Kang SM, Choe TB, An SK. The inhibition effect of Bletilla striata on melanogenesis in 
B16F10 mouse melanoma cells. Kor J Soci Tricho. $2007 ; 3: 5-20$.

23. Buscà R, Ballotti R. Cyclic AMP a key messenger in the regulation of skin pigmentation. Pigment Cell Res. $2000 ; 13$ : 60-9.

24. Kim JH, Park JK, Haw CR, Lee MH. The effects of multiple UVB exposures on proliferation and melanization in cultured human melanocytes. Kor $\mathrm{J}$ Dermatol. 1994 ; 32 : 1035-45.

25. Kim ST, Pataak MA, Hadley ME. Melanogenesis by UVA, UVB, PUVA and melanotropins in mouse and guinea pig skin. J Invest Dermatol. 1989 ; 92 : 459 .

26. Bertolotto C, Abbe P, Hemesath TJ, Bille K, Fisher DE, Ortonne JP, Ballotti R. Microphthalmia gene product as a signal transducer in cAMP-induced differentiation of melanocytes. J Cell Biol. 1998 ; 142 : 827-35.

27. Bertolotto C, Buscà R, Abbe $\mathrm{P}$, Bille K, Aberdam E, Ortonne JP, Ballotti R. Different cis-acting elements are involved in the regulation of TRP1 and TRP2 promoter activities by cyclic AMP: pivotal role of $\mathrm{M}$ boxes (GTCATGTGCT) and of microphthalmia. Mol Cell Biol. 1998 ; 18 : 694-702.

28. Han HS, Bae SJ, Kim MH. Effects of Porphyra tenera extracts on formation of collagen cross-link in ovarieectomized rars. J Kor Soc Food Sci Nutr. 2004 ; 33 : 324-30.

29. Park YJ, Yoon MY, Lim HW, Lee JY, Kim CJ, Sim SS. Effects of hot-water extracts from Laminnaria japonicus on production of melanin and inflammatory mediators. Yakhak Haeji. 2004 ; 48 : $374-8$

30. Chan YY, Kim KH, Cheah SH. Inhibitory effects of Sargassum polycystum on tyrosinase activity and melanin formation in B16F10 murine melanoma cells. J Ethnopharmacol. 2011 ; 137 : $1183-8$

31. Kim YS, Nam HG, Shin HJ, Na MS, Kim MH, Lee CW, Kim JS, Park OR, Cha WS, Nam HG. Effect of hot water extract of undaria pinnatifida on the activities of antioxidant and nitrite scavenging. KSBB. $2011 ; 26$ : 151-6.

32. Park MH, Kang SL, Kim MH. Effect of Codium Fragile extract on collagen content and collagen cross-link formation in ovariectomized rats. J Life Sci. 2007 ; 17 : 931-6.

33. Pharmacognosy. Dongmyungsa. 2006.

34. Park SM, Cho YG, Lee JR, Lee CW, Kim HJ, Kwan YG, Kim SC. Inhibitory effect of oyster conchioloin on pro-inflammatory mediator in lipopolysaccharide - Activated Raw 264.7 Cells.
Kor J Oriental Medical Pathology. 2008 ; 22 : 878-83. 